\title{
REPEATABILITY OF THE DURATION OF OESTRUS AND BREED DIFFERENCES IN THE RELATIONSHIP BETWEEN DURATION OF OESTRUS AND OVULATION RATE OF SHEEP
}

\author{
J. P. HANRAHAN AND J. F. QUIRKE \\ The Agricultural Institute, Belclare, Tuam, Co. Galway, Ireland
}

(Received 3rd December 1974)

\begin{abstract}
Summary. The duration of oestrus and the time interval from removal of progestagen-impregnated pessaries to the onset and end of oestrus were examined in Texel, Finnish Landrace, Galway and Fingalway (Finnish Landrace $\times$ Galway) ewes. The differences among the breeds in the relationship between these variables and ovulation rate at the controlled oestrus were also investigated. Breed differences were significant for all traits except the interval from pessary withdrawal to the onset of oestrus. The relationship between ovulation rate and both the interval from pessary withdrawal to the onset of oestrus and the duration of oestrus differed significantly among the breeds. The repeatability of the duration of oestrus was significant for Texel and Rambouillet ewes (mean $=0.5$ ) and for pooled data from ewe lambs of various breeds. It was concluded that, in view of the breed differences in the relationship between ovulation rate and duration of oestrus and other traits, generalizations should not be made from among-breed to withinbreed relationships. The high repeatability for the duration of oestrus may mean substantial heritabilities for the physiological determinants of oestrus duration.
\end{abstract}

\section{INTRODUCTION}

The duration of oestrus has been shown to be positively correlated with litter size in the Merino and Finnish Landrace breeds (Dunlop \& Tallis, 1964; Land, 1970). Land (1970) has also shown that breed differences in ovulation rate were positively associated with breed differences in the duration of heat. Subsequent investigations of the patterns of $\mathrm{LH}$ discharge during oestrus have shown that the length of the interval between the onset of oestrus and the discharge of LH was positively associated with ovulation rate between-breeds (Land et al., 1973) and within a breed (Thimonier \& Pelletier, 1971). The level of exogenous oestrogen has been shown to be positively associated with duration of oestrus (Scaramuzzi et al., 1971) and it has been suggested that gonadotrophic activity and level of oestrogen secretion at critical stages of the oestrous cycle could be used as selection criteria for the improvement of ovine fecundity (Land et al., 1972). The generality of these findings, from the point of view of understanding the basic physiological processes involved and as aids to 
selection for fecundity in sheep, needs to be evaluated. The results reported here are based on data collected during an egg-transfer experiment involving ewes of the Texel, Galway and Finnish Landrace breeds and the $F_{1}$ cross between the last two breeds (Fingalway) and in a study of reproduction in ewe lambs. The repeatability of the duration of oestrus was estimated for Texel and Rambouillet ewes and from data on Finnish Landrace, Galway, Finn-Dorset and $\frac{1}{4}$ Finn $\times \frac{3}{4}$ Galway ewe lambs.

\section{MATERIALS AND METHODS}

Experimental animals. All the animals were produced at the sheep breeding research farm near Ballinrobe, Co. Mayo $\left(53^{\circ} 36^{\prime} \mathrm{N}\right.$ and $\left.9^{\circ} 13^{\prime} \mathrm{W}\right)$ with the exception of the Texel ewes, which were of mixed age, born in 1968 or earlier and obtained on loan from the Department of Agriculture and Fisheries, Dublin on 19 October 1973. The main body of data reported in this paper concerns Texel, Finnish Landrace, Galway and Fingalway ewes. The Fingalway ewes were $F_{1}$ animals born to Galway ewes by Finnish Landrace rams. All ewes, apart from the Texels, were born in either 1967 or 1968 and the observations were made between October and December 1973. Average liveweights in October were $71 \cdot 5,50 \cdot 4,76.9$ and $67.3 \mathrm{~kg}$ for Texel, Finnish Landrace, Galway and Fingalway ewes, respectively. Data were also available on four genetic groups of 8- to 10-month-old ewe lambs (Finnish Landrace, Galway, FinnDorset (Finn ewes $\times$ Dorset rams) and $\frac{1}{4}$ Finn $\times \frac{3}{4}$ Galway (Fingalway ewes $\times$ Galway rams)) that were born in 1971 and observed during the 1971/1972 breeding season.

Oestrus and ovulation rate in mature ewes. Oestrus was synchronized, within the breeding season, in all mature ewes by the use of progestagen pessaries impregnated with $30 \mathrm{mg}$ 'Cronolone' (Synchromate: G. D. Searle), which were inserted into the anterior vagina of groups of ewes of mixed breed on 19 or 24 October or 2 or 9 November. Pessaries were withdrawn between 12 and 14 days after insertion. Within $12 \mathrm{hr}$ of pessary withdrawal ewes were checked for oestrus by being presented to either aproned or vasectomized rams. All ewes were checked individually every 3 hours until the end of oestrus. The end of oestrus was considered to occur $1.5 \mathrm{hr}$ after the last time a ewe stood to service. This was confirmed by testing all ewes until three successive tests established that a ewe would not accept the ram. A large pool of Finnish Landrace and Finn-Dorset rams was used.

Between Days 5 and 10 after the onset of oestrus, the ovulation rate of all ewes was measured by counting the number of CL during laparoscopy (Roberts, 1968) or laparotomy. The duration of oestrus in the Texel ewes was measured again one cycle later following a superovulatory dose of PMSG on Day 12 of the cycle, and during this oestrus the ewes were mated by fertile Texel rams.

Oestrus in ewe lambs. Ewe lambs were run with raddled, vasectomized rams as part of a study of reproduction in the ewe lamb (J. F. Quirke, unpublished work). Animals were individually checked twice daily for the presence of oestrus, and the duration of the first and second oestrus of the breeding season was used in the present analysis. 
Statistical analysis. The analysis of variance was used to examine the breed effects on the interval from sponge withdrawal to the end of oestrus (total interval) and its components: (1) the interval from sponge withdrawal to the onset of oestrus (before oestrus) and (2) the duration of oestrus. Ovulation rate was used as a covariate in parallel analyses in order to examine breed differences in the relationship between ovulation rate and the length of the various intervals. Duncan's multiple range test (Kramer, 1956) was used to compare breed means. Repeatability of the duration of oestrus was estimated on a pooled, withinbreed basis.

\section{RESULTS}

Mature ewes. The breed means for all traits measured are shown in Table 1 together with the number of animals involved, and the analyses of variance for the breed differences are presented in Table 2. The ovulation rates for Finnish Landrace, Galway and Fingalway ewes reflect differences among these breeds in litter size (Hanrahan \& More O'Ferrall, 1973). The ovulation rate for the

Table 1. Mean values for ovulation rate and the periods from sponge withdrawal to the end of oestrus in different breeds of sheep

\begin{tabular}{lllll}
\hline \multirow{2}{*}{ Trait } & \multicolumn{4}{c}{ Breed } \\
\cline { 2 - 5 } & Texel & $\begin{array}{c}\text { Finnish } \\
\text { Landrace }\end{array}$ & Galway & Fingalway \\
& & & \\
\hline No. of ewes & $20(20)^{*}$ & $32(38)$ & $23(30)$ & $16(30)$ \\
Ovulation rate & $1 \cdot 75^{\mathrm{e}}$ & $4 \cdot 03^{\mathrm{a}}$ & $1.53^{\mathrm{c}}$ & $2 \cdot 53^{\mathrm{b}}$ \\
Total interval (hr) $\dagger$ & $75 \cdot 4^{\mathrm{a}}$ & $74 \cdot 6^{\mathrm{a}}$ & $65 \cdot 9^{\mathrm{b}}$ & $69 \cdot 6^{\mathrm{ab}}$ \\
Before oestrus (hr) $\ddagger$ & $34 \cdot 9$ & $29 \cdot 7$ & $31 \cdot 2$ & $33 \cdot 0$ \\
Duration of oestrus (hr) & $40 \cdot 5^{\mathrm{ab}}$ & $\mathbf{4 5 \cdot 0 ^ { \mathrm { a } }}$ & $34 \cdot 7^{\mathrm{b}}$ & $36 \cdot 6^{\mathrm{b}}$ \\
\hline
\end{tabular}

Means in the same row which have no common superscript differ significantly $(P<0.05)$.

* Figures in parentheses are the numbers of ewes scored for ovulation rate.

$\dagger$ Time from sponge withdrawal to end of oestrus.

$\ddagger$ Total interval minus the duration of oestrus.

Texel ewes was higher than that for the Galway breed but was considerably lower than in the other two breeds. Breed differences were significant $(P<0.01)$ for the total interval from pessary withdrawal to the end of oestrus and for the duration of oestrus. Breed differences were not significant for the interval from pessary withdrawal to the onset of oestrus. With respect to the duration of oestrus the Finnish Landrace ewes had a significantly $(P<0 \cdot 05)$ higher mean value than either Galway or Fingalway ewes. The Texel ewes had an intermediate mean value and did not differ significantly from any other breed. This pattern was not reflected exactly in the mean length of the interval from sponge withdrawal to the end of oestrus. In this case the Texel ewes had the longest interval but this was not significantly longer than the value for Finnish Landrace ewes. However, both these breeds had a total interval which was 
significantly longer than that of Galway ewes; that of Fingalway ewes was intermediate. The change in ranking was due to non-significant differences in the length of the interval from sponge withdrawal to the onset of oestrus. There was a negative correlation within all breeds between the duration of oestrus and the interval from sponge withdrawal to the onset of oestrus. This relationship was not heterogeneous $(P>0.05)$ among breeds and the pooled correlation coefficient was $-0.37(P<0.01)$.

Table 2. Analysis of variance of breed differences in sheep in the periods from sponge withdrawal to the end of oestrus with ovulation rate as a covariate

\begin{tabular}{|c|c|c|c|c|}
\hline & \multicolumn{4}{|c|}{ Mean squares } \\
\hline & $\begin{array}{l}\text { Among } \\
\text { breeds }\end{array}$ & Regression & $\begin{array}{l}\text { Homogeneity } \\
\text { of regression }\end{array}$ & Error $\dagger$ \\
\hline $\begin{array}{l}\text { Total interval } \\
\text { Before oestrus } \\
\text { Duration of oestrus } \\
\text { Degrees of freedom }\end{array}$ & $\begin{array}{c}7154 \cdot 1 * * \\
122 \cdot 4 \\
536 \cdot 8 * * \\
3\end{array}$ & $\begin{array}{c}901 \cdot 4 * * \\
85 \cdot 8 \\
431 \cdot 1 * * \\
1\end{array}$ & $\begin{array}{c}94 \cdot 4 \\
552 \cdot 2^{* *} \\
271 \cdot 8 * \\
3\end{array}$ & $\begin{array}{c}129 \cdot 2 \\
111 \cdot 3 \\
92 \cdot 7 \\
87\end{array}$ \\
\hline
\end{tabular}

$* P<0.05 ; * * P<0.01$.

$\dagger$ The error mean square given is that appropriate for testing breed differences.

Table 3. Correlation coefficients between ovulation rate and the periods from sponge withdrawal to the end of oestrus in different breeds of sheep

\begin{tabular}{lcccc}
\hline & \multicolumn{4}{c}{ Breed } \\
\cline { 2 - 5 } Ovulation rate and & Texel & Finnish & Galway & Fingalway \\
\hline Total interval & $0.46^{*}$ & 0.27 & $0.41 *$ & 0.04 \\
Before oestrus & $0.65 * *$ & -0.25 & 0.26 & 0.02 \\
Duration of oestrus & $-0.41 \dagger$ & $0.48 *$ & 0.21 & 0.03 \\
\hline & & & & \\
\hline
\end{tabular}

The results of the analysis of breed differences in the relationship between ovulation rate and the length of the various time intervals are shown in Table 2. Significant heterogeneity was present for the duration of oestrus and for the interval from sponge withdrawal to the onset of oestrus. In contrast, the relationship between ovulation rate and the length of the interval from sponge withdrawal to the end of oestrus did not differ among breeds. The nature of the significant heterogeneity is summarized in Table 3 where the within-breed correlations are presented. Thus, in the Texel breed there is a negative relationship between the duration of oestrus and ovulation rate. The correlation between ovulation rate and the interval from sponge withdrawal to onset of oestrus is positive for the Texel ewes but negative for the Finnish Landrace ewes. When these intervals are combined to give the length of time from sponge withdrawal to the end of oestrus the relationship of this interval with ovulation rate is 
positive for all breeds. Comparison of mean values for Fingalway ewes with the appropriate mid-parent value indicated that there was no evidence for significant heterosis for any trait studied.

Ewe lambs. Table 4 shows the number of animals in each breed group which had one or at least two oestrous periods during the breeding season. Breed differences were significant $(P<0.05)$ for the duration of first oestrus but were not significant for the duration of second oestrus $(F=1 \cdot 26$, d.f. $=86)$. The average length of the first oestrus in Finnish Landrace ewe lambs was significantly greater than that for Galway or $\frac{1}{4}$ Finn $\times \frac{3}{4}$ Galway lambs, although the values for the Galway and Finnish Landrace breeds were almost identical at the second oestrus. This result is reflected in the average difference between the duration of the first and the second oestrous periods for ewes with at least two oestrous cycles. Thus, Finnish Landrace and Finn-Dorset ewe lambs exhibited small increases in the duration of oestrus whereas the Galway and $\frac{1}{4}$ Finn $\times \frac{3}{4}$ Galway ewe lambs showed large and significant increases in oestrus duration from the first to the second cycle.

Table 4. Duration of first and second oestrus in ewe lambs of four genetic groups

\begin{tabular}{lcccc}
\hline \multirow{2}{*}{ Breed group } & \multirow{2}{*}{$\begin{array}{c}\text { No. of } \\
\text { lambs }\end{array}$} & \multicolumn{3}{c}{ Duration of oestrus $(h r)$} \\
\cline { 3 - 5 } & & First & Second & Difference \\
\hline Finnish Landrace & $25(18)$ & $28 \cdot 6 \pm 2 \cdot 1$ & $30 \cdot 7 \pm 2 \cdot 1$ & $4 \cdot 3 \pm 3 \cdot 0$ \\
Galway & $65(39)$ & $22 \cdot 2 \pm 1 \cdot 3$ & $30 \cdot 8 \pm 1 \cdot 4$ & $9 \cdot 5 \pm 2 \cdot 0 * *$ \\
4.Finn $\times \frac{3}{4}$ Galway & $34(23)$ & $20 \cdot 4 \pm 1 \cdot 8$ & $27 \cdot 7 \pm 1 \cdot 9$ & $9 \cdot 1 \pm 2 \cdot 6^{* * *}$ \\
Finn-Dorset & $15(10)$ & $25 \cdot 6 \pm 2 \cdot 7$ & $25 \cdot 8 \pm 2 \cdot 8$ & $0 \cdot 6 \pm 4 \cdot 0$ \\
\hline
\end{tabular}

The figures in parentheses are the numbers of lambs experiencing a second oestrus.

$* * P<0.01$.

Repeatability of the duration of oestrus. The within-breed repeatability for the ewe lambs was computed since there was no significant heterogeneity among breeds with respect to the relationship between the duration of first and second oestrus. The repeatability for the Texel ewes and for the ewe lambs is given in Table 5. In addition, the repeatability of the duration of oestrus at successive cycles throughout the breeding season in three groups of ewes was computed from the data of Lamond et al. (1972). The among- and within-ewes components of variance were estimated and used to construct an estimate of repeatability. All estimates of repeatability were positive and for ewes both estimates were highly significant.

Text-figure 1 shows the relationship between the duration of the synchronized oestrus and that following PMSG in Texel ewes. One observation (indicated in the figure) was found to be a significant $(P<0.01)$ outlier (Tietjen et al., 1973). However, the exclusion of this animal changed the repeatability by only 0.005 and hence makes no difference to the value in Table 5. The paired differences between duration of oestrus in Texel ewes were examined after exclusion of the outlier. The oestrus after PMSG was $6 \cdot 0 \pm 1 \cdot 65 \mathrm{hr}$ shorter than that following synchronization treatment $(P<0.01)$. 
Table 5. Repeatability of the duration of oestrus in sheep

\begin{tabular}{lcc}
\hline Source of data & No. of animals & Repeatability \\
\hline Texel $\dagger$ & 20 & $0.64^{* *}$ \\
Ewe lambs & 90 & $0 \cdot 18^{*}$ \\
Rambouillet $\ddagger$ & 73 & $0.35^{* *}$ \\
\hline
\end{tabular}

$* P<0 \cdot 10 ; * * P<0 \cdot 01$.

$\dagger$ The second oestrus occurred after administration of PMSG.

¥ From data provided by $\mathrm{Dr}$ D. R.

Lamond from Lamond et al. (1972).

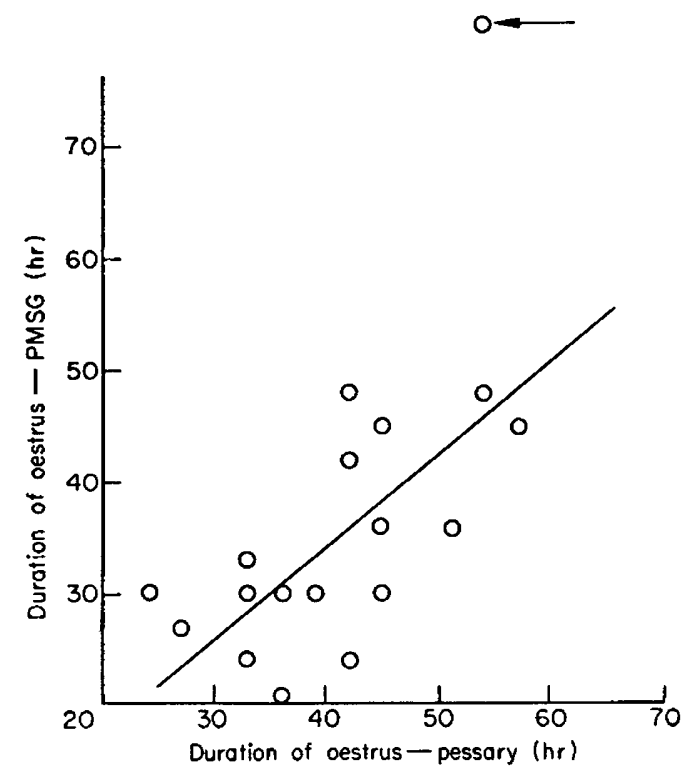

Text-Fig. 1. The observed values and linear regression $(y=0.61 x+9 \cdot 69)$ of the duration of oestrus after PMSG (y) on the duration of oestrus after withdrawal of progesteroneimpregnated sponge in Texel ewes. Note the single outlier (arrow).

\section{DISCUSSION}

Previous work on the relationship between the duration of oestrus and fecundity has shown this relationship to be positive (Dunlop \& Tallis, 1964; Colas, 1968; Land, 1970). Recent findings indicate that the interval from the onset of oestrus to the beginning of the $\mathrm{LH}$ surge is more closely related with ovulation rate than is the total amount of LH released (Thimonier \& Pelletier, 1971; Land et al., 1973). Land et al. (1972) reported that the pattern of oestrogen administration had a significant effect on the duration of oestrus in ovariectomized ewes. Thus, the duration of oestrus and ovulation rate seem to be directly related to the hormonal time patterns prevalent at the time of oestrus. Land et al. (1972) have suggested that estimates of gonadotrophic and oestrogenic activity can be 
used for the selection of sheep for improved reproductive performance. The generality of these conclusions needs to be confirmed. The present results seem to be at variance with previous findings in that there is a negative relationship between ovulation rate and the duration of oestrus in Texel ewes. In addition, if the breeds are ranked with respect to ovulation rate they will receive a different rank order on the basis of duration of oestrus. If, however, the Texel breed is excluded then the results for the remaining breed groups would agree with the results of Land (1970). Thus, the Texel breed might provide useful material for attempting to understand the physiological basis of variation in reproductive performance, although the negative correlation observed between ovulation rate and oestrus duration for Texel ewes was based on a small number of animals and was significant at the $10 \%$ level only.

In considering the pattern of relationships among the components of the period from pessary withdrawal to the end of oestrus and ovulation rate, the results in Table 3 suggest that all three pure breeds differ. However, the total period is positively associated with ovulation rate in all the breeds. This may suggest some unsuspected difficulty in the operational definition of the component intervals in that these are, in some way, breed-dependent. The breed differences observed in various manifestations of hormonal processes are not altogether surprising. There is no reason why two breeds could not achieve their ovulation rates by variations in different members of the complex set of physiological variables which are involved. These variations can readily be imagined to have different consequences for the pattern of oestrus and related phenomena. In general, particular danger attaches to generalizations from breed differences to within-breed relationships and such generalizations should not be made lightly.

Schindler \& Amir (1972) reported a value of 0.60 for the repeatability of natural oestrus in ewes, and the relatively high estimates of repeatability (unweighted mean value $=0.53$ for ewes) in the present study would indicate that there might be a reasonably high heritability for the duration of oestrus. Whether such a heritability would be expected for the individual components relating to the duration of oestrus can only be determined by direct investigation of these components. The fact that the duration of oestrus is significantly repeatable does, however, suggest that some of the physiological determinants of onset and duration of oestrus are highly repeatable and could provide a tool for more accurate selection of breeding stock in programmes for the genetic improvement of fecundity. Such a finding would also be of significance in that it would probably indicate the appropriate variables upon which to base the direct selection of male breeding stock (Land, 1971). This would increase the efficiency of such breeding programmes.

\section{ACKNOWLEDGMENTS}

The authors acknowledge the technical assistance of Miss K. Walsh, MrK. Brooks, Mr P. O'Dea, Mr T. Lally and Mr W. Loughnane and thank the Cloonagashel farm staff for care of the experimental animals, and Dr D. R. Lammond for providing the original data for inclusion in Table 5. 


\section{REFERENCES}

ColAs, G. (1968) Durée de l'oestrus et fertilité après insemination artificielle chez la brebis. Proc. 6th Int. Congr. Anim. Reprod. E̊ A.I., Paris 2, 1017-1019.

DunLoP, A.A. \& TALLIs, G.M. (1964) The effects of length of oestrus and number of inseminations on the fertility and twinning rate of the Merino ewe. Aust. F. agric. Res. 15, 282-288.

Hanrahan, J.P. \& More O'Ferrall, G.J. (1973) Effects of crossing Finnish Landrace and Galway sheep. Proc. Br. Soc. Anim. Prod. 2, 81.

KrAMER, G.Y. (1956) Extension of multiple range tests to group means with unequal numbers of replications. Biometrics 12, 307-310.

LAMOND, D.R., GADDY, R.G. \& KENNEDy, S.W. (1972) Influence of season and nutrition on luteal plasma progesterone in Rambouillet ewes. F. Anim. Sci. 34, 626-629.

LAND, R.B. (1970) A relationship between the duration of oestrus ovulation rate and litter size of sheep. 7. Reprod. Fert. 23, 49-53.

LAND, R.B. (1971) The incidence of oestrus during lactation in Finnish Landrace, Dorset Horn and Finn-Dorset sheep. 7. Reprod. Fert. 24, 345-352.

LAND, R.B., Thompson, R. \& BAIRD, D.T. (1972) The duration of oestrus of ovariectomized Finnish Landrace and Scottish Blackface ewes following progesterone and oestrogen treatment. $\mathcal{F}$. Reprod. Fert. 30, 39-44.

Land, R.B., Pelletier, J., Thimonier, J. \& Mauleon, P. (1973) A quantitive study of genetic differences in the incidence of oestrus, ovulation and plasma luteinizing hormone concentration in the sheep. F. Endocr. 58, 305-317.

Roberts, E.M. (1968) Endoscopy of the reproductive tract of the ewe. Proc. Austr. Soc. Anim. Prod. 7, 192-194.

Scaramuzzi, R.J., Lindsay, D.R. \& Shelton, J.N. (1971) The effect of oestradiol benzoate on the duration of oestrus behaviour in the ovariectomized ewe. F. Endocr. 50, 345-346.

SChINDLER, H. \& AMIR, D. (1972) Length of oestrus, duration of phenomena related to oestrus, and ovulation time in the local fat-tailed Awassi ewe. 7. agric. Sci., Camb. 78, 151-156.

Thmonier, J. \& Pelletier, J. (1971) Difference génétique dans la décharge ovulante (LH) chez les Brebis de race Ile-de-France; relation avec le nombre d'ovulations. Annls Biol. anim. Biochim. Biophys. 11, 559-567.

Tietjen, G.L., Moore, R.H. \& Beckman, R.J. (1973) Testing for a single outlier in simple linear regression. Technometrics $15,717-721$. 